


\title{
Bilingual memory advantage: Bilinguals use a common linguistic pattern as an aid to recall memory
}

International Journal of Bilingualism

(C) The Author(s) 2018

Article reuse guidelines: sagepub.com/journals-permissions DOI: $|0.1| 77 /|3670069| 88|438|$ journals.sagepub.com/home/ijb

(SAGE

\author{
Luna Filipović[GQ: 1] \\ University of East Anglia, UK
}

\begin{abstract}
Aims and objectives/purpose/research question: The aim of this study is to probe for language effects on bilingual episodic memory. The main research question is whether both languages of bilinguals are accessible and used as aids to memory regardless of which language is used for speaking, or whether each language used for verbalization affects memory in a languagespecific way.

Design/methodology/approach: Our methodology involves an experimental elicitation of event verbalizations and recall memory responses to video stimuli by English and Spanish monolinguals and proficient balanced bilinguals whose two languages are kept active throughout the experiment while they are describing what they see in one of the languages.

Data and analysis: The data analysis shows that there is a main effect of language, that is, the recall was overall more accurate in Spanish-speaking situations than in the English ones. However, the significance of the effect comes exclusively from the comparison between English monolinguals versus the other two groups: Spanish monolinguals and bilinguals. Spanish monolinguals and bilinguals speaking either English or Spanish all had better recall than the English monolingual participants.

Originality: Language effects on monolingual versus bilingual witness memory are seldom investigated and the current knowledge about bilingual episodic memory in general is very limited.

Significance/implications: This study informs the theoretical assumptions related to monolingual and bilingual thinking-for-speaking research as well as offering, for the first time, empirical support towards our understanding of how bilinguals proficient in both languages "merge" their linguistic systems when storing information about events they witness in memory regardless of the language used to explicitly describe the event in verbalization.
\end{abstract}

\section{Keywords}

Bilingual memory, causation, intentionality, English, Spanish 


\section{Introduction}

This paper is a study of bilingual memory for causation events. The aim was to probe for language effects on bilingual episodic memory and more specifically, to test whether there may be languagespecific effects on recall. There has been little interest and work on bilingual memory in general. As Altarriba and Heredia notice (2014: vii) [AQ: 2] among the many books written on bilingualism "hardly any books existed on memory and language", which these authors consider an unfortunate oversight. The relationship between language and memory has been a topic of inquiry in psycholinguistics for quite some time, although the empirical data usually come from monolingual speakers. Increasingly, with the multilingual turn in language-related disciplines, more attention is being paid to bilingual memory representation (see Altarriba \& Isurin, 2010; [AQ: 3] Heredia \& Altarriba, 2014).

Research in bilingual processing has mainly been concerned with how much of the syntactic representations is shared in the bilingual mind, and most would argue that they are shared to a great degree, as much as the two systems would allow (discussed further in Discussion section). What has not been studied very much is how the syntactic shape of a sentence used by a bilingual may shape memory for the event described, although some studies have addressed this issue, for example, Fausey and Borditsky $(2010,2011)$ [AQ: 4] in monolingual contexts and Filipović (2011, 2018) in bilingual contexts.

In the present study I investigate the possibility that fully fluent bilinguals with balanced proficiency may use resources of both their languages as an aid to memory even though they verbalize events in only one of their two languages. In other words, having access to two systems for the organization of witnessed experience may be an advantage over having a single (monolingual) system because different linguistic rules or habits of use may require speakers of different languages to draw different distinctions at both the lexical and the syntactic levels. These distinctions may be crucial for the representation of events in language and memory, and bilinguals may be in an advantageous position as a result due to multiple encoding patterns and multiple conceptual features active at the same time.

\section{Bilingualism: briefly on the relevant factors}

Many different factors seem to affect bilingual language competence, such as age of acquisition, based on which we can divide bilinguals into early versus late, or relative proficiency and frequency of use, which leads to the balanced versus unbalanced dichotomy (see Treffers-Daller, 2015). Other factors are also at play, such as the level of activation of each language in specific communicative situations (i.e. language mode; Grosjean, 2001) or level of formality of the linguistic interaction in question (Dewaele, 2001). There is an ongoing debate as to which factors are decisive on what occasions.

Classifying bilinguals is not universally agreed. For our purposes here we are focusing on bilinguals who are equally or nearly equally proficient in both languages and use both with a similar frequency in their daily lives. I use the same stimuli and methodology as an earlier study that involved a different type of bilingual speaker (second language learners; Filipović, 2018). This is done in order to examine populations with different relative proficiencies in the two languages in focus: English and Spanish. Previous research has shown that early (simultaneous) bilinguals have advantages in cognitive control that are not detected in late bilinguals and monolinguals (Luk, De Sa, \& Bialystock, 2011). Furthermore, previous studies have found differences in linguistic performance between early and late bilinguals, for example, in processing syntactic attachment ambiguity (Dussias, 2001) and in categorization of motion events (Lai et al., 2014). Kroll and Bialystock 
(2013) [AQ: 5] have argued that highly proficient bilinguals (early bilinguals and very highly competent L2 speakers) activate information about both languages when they are speaking one of them. If both linguistic systems are regularly accessible and used by bilingual speakers, then we can expect them to resort to both for memory, which would lead to more information about events being available. This is because different languages make different features obligatory to express and bilinguals need to make information available for lexicalization in both languages, and the bilinguals would need to think for speaking in both.

\section{Bilingual memory: a brief general overview}

While not all memories are linguistic (e.g. they could be senso-motor, tactile or olfactory), language is often used to describe, trigger or evoke memories as well as store them. Encoding of memories seems to be language-specific, which does not mean that those memories are locked away for access only via the language they were encoded in. It is just that "episodic memories are integrative and preserve a large amount of context across modalities" (Bartolotti \& Marian, 2013: 10), [AQ: 6] and the context includes the linguistic environment related to the event that the memory is about. Thus, the kind of information available for later retrieval may in part be conditioned by the systems used to encode it. Semantic memory on the other hand may "forgo linking concepts to specific languages" (Bartolotti \& Marian, 2013: 10).

Experimental testing of bilingual witness memory is in its infancy. There are very few studies that address the question of how perception and verbalization may affect recognition or recall in bilingual eyewitnesses. Monolingual witness memory and judgement has been the subject of previous empirical research in psycholinguistics. Ever since Loftus and Palmer's (1974) seminal study we have known that language used to describe events may affect the ways in which witnessed events are remembered. Namely, speakers witnessing the same events can entertain different memories about them based on the different descriptions they hear during the viewing phase of an experiment. Language effects on bilingual memory have been much less explored in the literature. One such study is Filipović (2011), which looked at how monolingual speakers of English and Spanish and English-Spanish bilinguals express and remember motion events. The study found that there are differences in memory between the two monolingual populations due to the different structural preferences of the two languages. The English pattern induces speakers to habitually express manner in the verb (e.g. as in 'he limped out'), whereas Spanish does not lexicalize manner in an obligatory constituent (the verb), although it can be expressed in an optional constituent (e.g. a gerund; as in 'salió cojeando' = 'he/she exited limping'). English participants remember the manner of motion better than Spanish speakers. Interestingly, the same study showed that bilingual speakers' memory performance in that task was the same as that of Spanish monolinguals. Filipović (2011) explains that this is due to the fact that the Spanish pattern can be used in both English and Spanish while the English pattern is blocked in Spanish, due to syntactic and semantic restrictions in that language (see Aske, 1989; Filipović, 2008; Slobin, 1996, 2003, 2006).

Adoption of a single syntactic pattern in both languages (whatever-works-in-both) by bilinguals has been reported in a variety of different studies of bilingual processing (e.g. see Nicol, Teller, \& Greth, 2001 for verb agreement and Hohenstein, Esienberg, \& Naigles, 2006 for semantic categorization), and it is well-documented in sociolinguistic literature on historic language change driven by bilingual use (see Heine \& Kuteva, 2005; Trudgill, 2011 for numerous case studies of bilingualism and language contact). Recently, a new model of bilingual language processing was put forward that captures this efficiency-driven mechanism to "maximize common ground" (i.e. sharing or making commonalities in meaning) within and across bilingual minds (Filipović \& Hawkins, 2018). 


\section{The cognitive domain of causation in language and memory}

Causation is a ubiquitous and existentially primary cognitive domain. Speakers talk about the causes and effects of events on a daily basis, regardless of the language they speak. Languages vary with respect to how they divide the continuum of possible meanings related to causation. There can also be more than one option for describing a causation event even within a single language. For example, in English one and the same event can be described as "Jill broke a vase", "The vase was/ got broken" or "The vase broke", depending on how much information we know or want to reveal about the event and how much agency we observed or felt was involved. Both English and Spanish have multiple options for expressing events in this domain, whereby different structures refer to different levels of "blameworthiness" (Gibbons, 2003).

However, there are also differences between the resources in the two languages. Spanish has the se-constructions that clearly indicate non-intentional causation. For example, the construction "se me cayó" (meaning "to me it so happened that something was dropped/something fell") indicates that there may have been an agent involved in the event of something being dropped but the involvement was involuntary (i.e. non-intentional). This construction is called "affective dative" and represents, according to Pountain (2003: 116) a most frequent feature in the Spanish language due to its preference and frequency in use. There is no real equivalent for this structure in English, except perhaps a few marginal examples with limited frequency where only few verbs occur (e.g. 'The car engine died on me'), far less productive than the Spanish se-constructions. However, in this case, even the rare and unproductive English construction would not work (e.g. 'She fell on me'), since the unintended locative interpretation (that she fell on top of me) would be the clearly dominant one. The key point here is not so much whether constructional options are available but rather how frequently they are used and how this affects how events will be verbalized and what distinctions will be drawn in language. The most frequently used SVO structure in English is ambiguous with regard to intentionality while the Spanish language makes it explicit and clear if something was non-intentional because only se-constructions can be used to refer to it while the SVO structure in Spanish is reserved for intentional actions.

These structural and usage tendencies in the two languages have already been shown to have consequences for eyewitness memory in monolingual speakers and L2 learners (see Fausey \& Boroditsky, 2011; Filipović, 2013, 2018). But what happens when both languages are equal in terms of proficiency?

\section{The current study}

\section{Participants}

The bilingual population in this study consisted of 20 participants who came from the United States of America, but who were located in Cambridge, England, when the data collection was carried out. They were all born in the USA and, for each, both parents were Spanish speakers. They all grew up speaking only or mainly Spanish at home or privately with family. They were schooled mainly in English, although some (3 out of 20) had bilingual education. The mean age of the population was 24 (range: range 22-26). Four of the participants were married to Spanish-speaking partners. Two participants had one child each and were speaking to their children in Spanish only, although the children were attending English-speaking nursery schools. Seven of the bilinguals spoke an additional language but only at a beginner or low intermediate level.

We also have two baseline populations for comparison, 20 English monolingual speakers who were students at the time at either the University of Cambridge or the University of East Anglia 
Table I. Experimental video stimuli.

\begin{tabular}{ll}
\hline Intentional events & Non-intentional events \\
\hline Girl pops an orange balloon with a needle & Blue balloon pops while a girl is playing with it \\
Girl pushes a Barbie doll off the bed & A cup is pushed off the while washing hands \\
Woman crushes a plastic cup in her hand & A wooden toy tower gets crushed by a woman falling on it \\
Woman drops a magazine onto the floor & $\begin{array}{l}\text { A pen is dropped during writing } \\
\text { A bottle is knocked off the table while rummaging through } \\
\text { things located on it }\end{array}$ \\
\hline
\end{tabular}

(mean age 20, range 19-25, 9 male, 11 female) and 20 Spanish monolingual speakers (mean age 21, range 18-26, 8 male, 12 female), all university students at the University of Zaragoza, Spain. Our monolingual populations were not completely monolingual since they all learned a second language during their education. However, they did not take their language further than the secondary school level and were using it only or mainly when travelling.

All participants performed a short memory test that included looking at two blocks of 20 objects for 20 minutes and listing the items after a 5-minute break for each block (https://faculty. washington.edu/chudler/puzmatch1.html). The recall rate difference was $10 \%$ maximum among the participants (the difference in objects remembered was one or two at the most), which indicates that there were no substantial differences in general memory among the participants. Bilingual participants also did an online language proficiency test for Spanish (https://www.transparent.com/language-resources/tests.html). There were no significant differences among the bilingual participants in proficiency for either language. They were included in the study only if their score in each language was $95 \%$ and above correct.

\section{Stimuli}

The materials and method in this study were identical to those used in Filipović (2018). This would enable subsequent comparisons between second language learners of English and Spanish (Filipović, 2018) with speakers who have equal proficiency in both these languages (current study). The stimuli consisted of video clips filmed with a Sony DCR-HC18E digital video camera, and the experiment was run on a portable PC laptop using Microsoft Office PowerPoint. Each target video clip contained an event with either an intentional or a non-intentional causation event (e.g. a girl popping a balloon on purpose versus a girl playing with a balloon that popped accidentally, clearly surprising her). There were 10 target videos and 10 filler videos. The filler videos depicted noncausation events, for example, a man drinking coffee. All the target videos were matched for action type (e.g. both intentional and non-intentional breaking events were witnessed by all participants). All the videos were pilot-tested by two native speakers of each language in order to ensure that they were uniformly judged as either intentional or non-intentional. The target videos are described in Table 1.

\section{Procedure}

The procedure was the same as that followed in Filipovic $(2013,2018)$. Participants were shown the target videos and were asked to describe them in either English or Spanish. (They were given three practice videos as a warm-up.) Subsequently, after a short intervening break, they were given a recall task in which they were asked whether they had seen particular events. 
For the video description, they were told that they would be watching videos of the duration between six and nine seconds, depicting various actions, and that their task was to verbalize what had happened after each video clip (verbalization stage). The bilingual participants heard and used both their languages throughout the experiment. Each performed half of the experiment verbalizing in English while hearing the instructions in Spanish and then the reverse for the other half of the experiment, that is, verbalizing in Spanish while listening to the instructions in English. They were randomly assigned to English-first or Spanish-first groups.

The stimuli were balanced between the two bilingual groups (Spanish-first and English-first respectively) in the following way. One list was created for both groups. The Spanish-first group verbalized four target items and six filler items in Spanish and six target items and four filler items in the second block in English. The English-first bilinguals did exactly the opposite: four target + six filler items in the first block in English and then six target and four filler items in Spanish in the second block. The items were randomized within each block for both groups to avoid recency bias in items.

The intervening distractor task consisted of a 120-second task in which a $10 \times 10$ grid of randomised letters was shown on the screen, and the participants were asked to count how many of the letters $\mathrm{M}, \mathrm{N}$ and $\mathrm{Z}$ they could see.

The recall task asked two questions about each of the witnessed events (e.g. Did you see a girl with a Barbie doll? Was what happened in that video accidental or on purpose?). They were asked to mark their answers on an answer sheet by circling YES if the action in the video was on purpose (intentional) and NO if it was not on purpose (i.e. it was accidental/non-intentional). They were also told that they should not guess and that they should leave a question unanswered if they were not able to recall the relevant information. Responses were classified as incorrect if the participants circled the wrong answer (e.g. intentional instead of non-intentional) or if they failed to give any response (i.e. they left both options unmarked because they could not recall the crucial piece of information; this was the case in $17 \%$ of all responses for all groups). Further post-hoc verbalizations were collected from all bilingual participants in order to obtain equal numbers of verbalizations for each video to those of both languages as monolinguals (since the bilinguals had described only four to six of the videos in each language). Bilinguals verbalized each video again in the language different to the one used for the given video during the experiment.

\section{Hypotheses}

Following the thinking-for-speaking hypothesis (Slobin, 1996, 1997, 2003, 2006) and the previously reported language-specific effects on monolingual episodic memory (Filipović, 2011, 2013), I expected the Spanish monolingual speakers to have better recall of whether the causation was intentional or not than the English monolingual speakers. This is because the Spanish lexicalization pattern requires speakers to draw the relevant distinctions with regard to intentionality while English leaves this piece of information largely ambiguous (as shown in Filipović, 2013).

I also hypothesized, based on previous research (Filipović, 2013), that both constructions 'She pushed the bottle off the table' and 'The bottle fell off' (Table 1, examples (2a) and (2c)) [AQ: 7] would be used by English monolingual participants to refer to either intentional or non-intentional events indiscriminately. By contrast, Spanish monolingual speakers were expected to use intentional and non-intentional constructions consistently for intentional and non-intentional events respectively (Table 1, examples (1a) and (1d)) [AQ: 8] in order to signal clearly when an event they witnessed was intentional and when it was not.

I based the central hypothesis regarding the bilingual speakers on the recent model CASP for Bilingualism (Filipović \& Hawkins, 2018), which predicts that bilinguals would use a shared 
mechanism for expressing and remembering causation events that would work in both languages (i.e. they would maximize common ground in CASP terms), thus having the same recall outcomes regardless of the language explicitly used for verbalization. In other words, the prediction was that bilinguals would not be influenced by the language of operation and that their memory for causation events would not be less accurate when they verbalized events in English, indicating that resources from both languages are employed as aids to memory regardless of which language is used for speaking. If, on the other hand, the language of operation was a strong factor, we would then expect to see more detail in the description of events and better recall when the bilinguals were speaking Spanish than when they were speaking English.

\section{Results}

\section{Verbal descriptions}

The monolingual speakers verbalized in line with the predictions: English monolinguals tended not to draw regular and explicit distinctions between intentional and non-intentional events and left their descriptions ambiguous (as in (5a) and (5b)). They explicitly specified events as non-intentional in only $26 \%$ of the cases and as non-intentional in $20 \%$ of verbalizations (see Appendix). By contrast, the Spanish monolingual participants consistently distinguished between intentional and non-intentional events, as in (6a) and (6b), using SVO constructions for the former in $100 \%$ of cases and the se construction for the latter in $100 \%$ of cases (see Appendix for more details about responses across all groups):

(5a) [intentional event:] The woman was carrying a magazine and she dropped it on the floor.

(5b) [accidental event:] A woman knocked the bottle off the desk.

(6a) La mujer tiró la revista al suelo.

The woman throw-PST.3SG the magazine on-the floor.

(6b) Se cayó la botella a la muchacha.

PART fall-PST.3SG the bottle to the girl

To the girl it happened that the bottle fell.

Bilinguals showed clear differentiation between intentional and non-intentional events in both English and Spanish. Their verbalizations of non-intentional events in Spanish closely resembled that of the Spanish monolinguals - they used se-constructions $100 \%$ of the time, either with the affective dative le ('se le cayó' = 'to him/her it fell'; $65 \%$ of instances) or without it ('se cayó' = 'it fell; in $45 \%$ of the cases). In English, they described non-intentional events by either using SVO constructions with added adverbial modification (49\% of instances) or via the use of inchoative constructions ('The balloon popped'; 47\%). For intentional actions, they only used the SVO constructions (100\%) in both languages. They added adverbial modification in English in $41 \%$ to indicate intentionality (e.g. on purpose or 'forcefully'). In most cases when they did not use additional adverbials, the verbs they used gave a clear indication of intentionality because they referred to actions performed with a considerable force (e.g. 'The woman crushed/destroyed the cup' or 'She threw the magazine onto the floor'; see Ibarretxe-Antuñano, 2012 on the relationship between force and intentionality in lexicalization). The examples of bilingual verbalizations are given below:

(3a) The woman threw the magazine down onto the floor. (intentional)

(3b) The girl popped the balloon. (intentional) 
(3c) The woman moved something on the table and the bottle fell down, from the table. (non-intentional)

(3d) The girl's balloon popped by accident. (non-intentional)

(4a) Tiró la revista al suelo.

Throw -PST.3SG the magazine on-the floor.

'The woman threw the magazine onto the floor'. (intentional)

(4b) La mujer buscaba algo sobre la mesa y se le cayó la botella.

The woman looked for something on the table and PART she-DAT fall-PAST.3SG the bottle.

'The woman was looking for something on the table and the bottle (accidentally) fell.' (non-intentional)

\section{Recall}

Recall errors concerning the intentionality of the video action from monolinguals and bilinguals in each language were turned into proportions incorrect, because monolinguals had described all 10 videos in their language, while bilinguals had described four videos in one language and six in the other. These proportions were transformed into arcsin scores for the purposes of statistical analyses. I carried out multiple 2 (Group) x2 (Condition-intentional/nonintentional) ANOVA analyses, comparing the two monolingual groups as well as bilinguals speaking Spanish with both monolingual groups and bilinguals speaking English with both monolingual groups. There was a main effect of language in the monolingual English-Spanish comparison $(F=9.90 ; d f=1.00 ; p=.003)$ and a significant Intentionality X Group interaction $(F=13.28 ; d f=1 ; p=.001)$. Independent sample t-tests were significant for group differences in the non-intentionality condition only ( $t=$ 4.103; $d f=38 ; p<.001)$. In the comparison of bilinguals speaking English and English monolinguals there was also a main effect of group $(F=11.68 ; d f=1.00 ; p=.002)$ and a significant interaction of Group X Condition $(F=11.14 ; d f=1.00 ; p=.002 ;)$. The t-tests revealed that, again, the difference between the groups lay in the recall for non-intentional items only $(t=-3.89 ; d f=38$; $p<.001)$. Bilinguals speaking Spanish also differed from the monolingual English speakers in the number of recall errors. There was a main effect of group $(F=10.78 ; d f=1.00 ; p=.002)$ and a significant interaction of Group X Condition $(F=14.96 ; d f=1.00 ; p<.001)$. In this case as well the independent sample t-tests reached significance only for the non-intentional condition $(t=$ $-4.33 ; d f=38 ; p<.001)$. No other comparison resulted in significance $(p>.05$ for bilinguals when speaking Spanish versus Spanish monolinguals, for bilinguals when speaking English versus Spanish monolinguals, and for bilinguals speaking English versus bilinguals speaking Spanish). The means for errors in recall of intentionality (in arcsin scores) are given in Table 2.

\section{Discussion}

\section{Interpreting monolingual and bilingual results}

We investigated whether different patterns in the lexicalization of causation in English and Spanish resulted in differences for recall memory in monolingual and bilingual populations. The results show that Spanish and English monolinguals speakers differed in both how they described and how they recalled events. Spanish speakers use two distinct constructions: one for intentional and one for non-intentional events as predicted by the lexicalization pattern (and as illustrated in the Appendix). English speakers use both SVO and inchoative constructions across the different 
Table 2. Mean percent errors values for recall.

\begin{tabular}{lclll}
\hline $\begin{array}{l}\text { Descriptions } \rightarrow \\
\text { Groups }\end{array}$ & English intentional & $\begin{array}{l}\text { English } \\
\text { non-intentional }\end{array}$ & Spanish intentional & $\begin{array}{l}\text { Spanish } \\
\text { non-intentional }\end{array}$ \\
\hline $\begin{array}{l}\text { English monolinguals } \\
\text { Spanish monolinguals }\end{array}$ & 12.00 & 49.55 & 15.20 & 12.45 \\
Bilinguals & 13.75 & 14.20 & 13.75 & 10.70 \\
\hline
\end{tabular}

events, not discriminating explicitly between intentional and non-intentional meanings. They also only very occasionally disambiguate the SVO constructions with adverbials (e.g. "She dropped the cup accidentally"). Recall that differences between the two monolingual populations were also found with respect to non-intentional items in the experimental stimuli, while the intentional events did not elicit any significant differences. Intentional events can be described using the same means in both languages (simple transitive SVO constructions) while the unintentional events are described differently in the two languages (typically the same SVO constructions in English vs. se-constructions in Spanish). Our results support findings from previous research that indicated that both verbalization and memory between English and Spanish participants pertains to the nonintentional event stimuli in particular (Fausey \& Boroditsky, 2011; Filipović, 2013). The reason for this may be because prototypical transitivity does indeed involve intentionality, as Hopper and Thompson (1980) [AQ: 9] point out. A transitive agent is normally an intentional instigator or a causer of the action. There is a strong relationship in English between the subject function (and its sentence-initial position) and the agent role, reflected in the fact that subjects are indeed most frequently agents and, as Fausey and Borodistky (2011) have shown, the focus on agents is more pronounced in English than in Spanish. Thus, SVO structures in English may inspire an agentive interpretation more often than the non-agentive one, and that could have interfered with recall for non-intentional events.

We also may have to allow for the possibility that the mere nature of the stimuli is positively skewed towards the salience of intentionality, for example, in our stimuli, a girl approaches the bed on which a Barbie doll is positioned, looks at the doll and pushes it off the bed, whereby the intention to perform the action is clear. On the other hand, non-intentional events all had an element of surprise and unexpectedness, which may affect the amount of detail that is recorded, especially if language does not encourage the encoding of certain details (such as whether the action was on purpose or not). In the case of non-intentional event stimuli there was more information to be integrated and more inferences to be made in order to encode them fully in memory (e.g. judge the behaviour of the agent before and after the balloon popped). Having clear labels for distinguishing intentional and non-intentional events means that this encoding in language and memory was facilitated for Spanish speakers and Spanish-English bilinguals. Finally, some verbs may have more inherent intentionality in them than others (e.g. push vs. drop; see Filipović, 2018, forthcoming for more discussion). This is a matter for further exploration with an experimental design that would specifically target such contrasts and control for the differences in default interpretations in individual speakers.

It is interesting to point out that bilinguals in this study did not perform differently based on the language of the operation (i.e. the one they were verbalizing in). When we look at the ways bilinguals verbalized during the experiment, we can see that that they were drawing explicit distinctions between intentional and non-intentional events in both languages (see Appendix).

It is worth noting that the effect we report here may be weaker or disappear altogether if bilinguals are in a monolingual mode (Grosjean, 2001), due either to the specifications of a 
communicative situation or to experimental conditions (e.g. when access to one language is blocked through interference). However, when access is uninhibited and especially when both systems are highly active in a communicative situation (or entrenched through habitual use of both), bilinguals are more likely to draw on the relevant lexical, grammatical and conceptual differences from both languages when speaking either of their languages.

\section{Conclusions and further research prospects}

In this paper we presented evidence for a bilingual memory advantage for recall memory. Cognitive advantages of bilingualism have been documented (e.g. Bialystok et al., 2005; Bialystok et al., 2007) and disputed (Papp et al., 2015; Papp et al., 2016) in various contexts in previous research. A benefit (or lack of it) for bilingual witness memory has not been discussed before. It seems to be generally beneficial to harness the potential of multiple ways of looking at the same situation. This benefit is detected when the two languages in the bilingual mind do not share identical lexicalization patterns and bilinguals create shared patterns by introducing distinctions from the language that has those distinctions into the one that does not have them. This study has shown that the benefits of this mechanism go beyond the differences in the amount of detail in verbalized events because they affect memory recall for verbalized events as well.

We can now also reflect on what our findings mean for our understanding of bilingualism more generally. We believe that bilingual processing is optimally efficient even though it may not always be economical (Filipović, 2014; Filipović \& Hawkins, 2013, 2018). Bilingual speakers introduce categories from one language into another even though this is not required or obligatory, so this may not be an economical option. However, we argue that it is nevertheless the most efficient option and that it is beneficial to do so. This is because if one of the two languages makes some distinctions obligatory, it is easier to always be ready to make those distinctions in both languages because in that way the more cognitively costly constant switch between two different systems is avoided. This is in line with what Silva-Corvalán (1994) also argues, namely that "in language-contact situation bilinguals develop strategies aimed at lightening the cognitive load of having to remember and use two different linguistic systems" (p. 206). This is particularly the case with bilingual speakers who are frequent users of both languages and in particular those that use both languages in single communicative situations (e.g. multilingual meetings in the work place or interpreting).

It is important to point out that bilingual minds are not constantly creating new categories or introducing new meaning distinctions from one language into the other. In fact, bilingual minds seem to resort to different strategies in the way they handle typological differences between their two languages. As we discussed earlier, when a shared pattern exists, it is more likely to be used by bilinguals even though it may negatively affect how much detail is verbalized and remembered (as in the case of memory for motion events; see Filipović, 2011). However, when there is no readily available shared pattern and bilinguals introduce new meanings from one language into the other, then this results in beneficial memory outcomes when either language is used, as shown in the current study. This benefit is also available to L2 learners, if they have the relevant distinctions in their L1 that they introduce into their L2 (e.g. L1 Spanish learners of L2 English; Filipović, 2016) [AQ: 10]. As suggested in Filipović (2016), and also reinforced here, raising awareness about the relevant lexicalized conceptual and perceivable distinctions in the context of an L2 classroom may lead to memory benefits of those speakers who do not have the relevant distinctive categories in their L1 but may import them from their L2 (such as L1 English learners of L2 Spanish).

Further studies like the one presented in this paper, which would include many more languages and language combinations as well as many other cognitive domains, will enable us to come significantly closer to a better understanding of how the bilingual mind works. 


\section{Acknowledgement}

I would like to thank Ginny Gathercole for extensive and insightful comments that were of immense help in the preparation of this paper. I am also grateful to Sharon Geva and Paul Engelhardt for their help with the processing of the data. My thanks go to Iraide Ibarretxe-Antuñano as well, who made it possible for me to collect the Spanish monolingual data. Any remaining errors are exclusively mine.

\section{Declaration of conflicting interest[GQ: 2]}

The author declares that there is no conflict of interest.

\section{Funding}

This research received no specific grant from any funding agency in the public, commercial, or not-for-profit sectors.

\section{References}

Abutalebi, J., Cappa, S. F., \& Perani, D. (2009). What can functional neuroimaging tell us about the bilingual brain? In J. F. Kroll \& A. M. B. de Groot (Eds.), Handbook of bilingualism (pp. 497-515). Oxford, UK: Oxford University Press.

Altarriba, J., \& Isurin, L. (2013). Memory, language, and bilingualism: Theoretical and applied approaches. Cambridge, UK: Cambridge University Press.

Aske, J. (1989). Path predicates in English and Spanish: A closer look. Proceedings of the Fifteenth Annual Meeting of the Berkeley Linguistics Society, Berkeley, CA, 1-14.

Bialystok, E., Craik, F. I. M., \& Freedman, M. (2007). Bilingualism as protection against the onset of symptoms of dementia. Neuropsychologia, 45, 459-464.

Bialystok, E., Craik, F. I. M., Grady, C., Chau, W., Ishii, R., Gunji, A., \& Pantev, C. (2005) Effect of bilingualism on cognitive control in the Simon task: Evidence from MEG. Neuroimage, 24, 40-49.

Cadierno, T. (2010). Motion in Danish as a second language: Does the learner's L1 make a difference? In Z-H. Han \& T. Cadierno (Eds.), Linguistic relativity in SLA (pp. 1-33). Clevedon, UK: Multilingual Matters.

Dewaele, J.-M. (2001). Activation or inhibition? The interaction of L1, L2 and L3 on the language mode continuum. In J. Cenoz, B. Hufeisen, \& U. Jessner (Eds.) Cross-linguistic influence in third language acquisition: Psycholinguistic perspectives (pp. 69-89). Clevedon, UK: Multilingual Matters.

Dussias, P. E. (2001). Sentence parsing in fluent Spanish-English bilinguals. In J. Nicol (Ed.), One mind, two languages: Bilingual language processing (pp. 159-176). London, UK: Blackwell.

Fausey, C., \& Boroditsky, L. (2011). Who dunnit? Cross-linguistic differences in eye-witness memory. Psychonomic Bulletin and Review, 18, 150-157.

Filipović, L. (2008) Typology in action: Applying insights from typological contrasts. International Journal of Applied Linguistics, 18(1), 42-61.

Filipović, L. (2011). Speaking and remembering in one or two languages: Bilingual vs. monolingual lexicalization and memory for motion events. International Journal of Bilingualism, 15, 466-485.

Filipović, L. (2013). Constructing causation in language and memory: Implications for access to justice in multilingual interactions. International Journal of Speech, Language and the Law, 20, 1-19.

Filipović, L. (2014). Efficiency of the bilingual mind: Clues from processing, memory and second language acquisition studies. In L. Filipović \& M. Pütz (Eds.), Multilingual cognition and language use: Processing and typological perspectives [Human Cognitive Processing Series 44] (pp. 205-227). Amsterdam, the Netherlands: John Benjamins.

Filipović, L. (2018). Speaking in L2 but thinking in L1: Language-specific effects on memory for causation events in English and Spanish. International Journal of Bilingualism, 22, 180-198.

Filipović, L. (forthcoming). Bilingualism in action: Theory and practice. Cambridge, UK: Cambridge University Press.

Filipović, L., \& Hawkins, J. A. (2013). Multiple factors in second language acquisition: The CASP model. Linguistics, 51, 145-176. 
Filipović, L., \& Hawkins, J. A. (2018). CASP model for bilingualism: Language interactions within and across bilingual minds. International Journal of Bilingualism.[AQ: 12]

Gibbons, J. (2003). Forensic linguistics. Oxford, UK: Blackwell.

Grosjean, F. (2001). The bilingual's language modes. In J. Nicol (Ed.), One mind, two languages: Bilingual language processing (pp. 1-22). Oxford, UK: Blackwell.

Heine, B., \& Kuteva, T. (2005). Language contact and grammatical change. Cambridge, UK: Cambridge University Press.

Heredia, R. H., \& Altarriba, J. (2014). Foundations of bilingual memory. New York, NY: Springer.

Hohenstein, J., Eisenberg, A., \& Naigles, L. (2006). is he floating across or crossing afloat? Corss-lingusitic influences of L1 and L2 in Spanish - English bilingual adults. Bilingualism; Language and Cognition, 9(3), 249-261.

Ibarretxe-Antuñano, I. (2012). Placement and removal events in Basque and Spanish. In A. Kopecka \& B. Narasimham (Eds.), The events of putting and taking. A crosslinguistic perspective (pp. 123-143). Amsterdam, the Netherlands: John Benjamins.

Ibarretxe-Antuñano, I., \& Filipović, L. (2013). Lexicalization patterns and translation. In A. Rojo \& I. Ibarretxe-Antuñano (Eds.), Cognitive linguistics and translation (pp. 253-284). Berlin, Germany: Mouton de Gruyter.

Lai, V. T., Garrido Rodriguez, G., \& Narasimhan, B. (2014). Thinking-for-speaking in early and late bilinguals. Bilingualism: Language and Cognition, 17, 139-152.

Loftus, E. F., \& Palmer, J. C. (1974). Reconstruction of auto-mobile destruction: An example of the interaction between language and memory. Journal of Verbal Learning and Verbal Behavior, 13, 585-589.

Luk, G., De Sa, E., \& Bialystock, E. (2011). Is there a relation between onset age of bilingualism and enhancement of cognitive control? Bilingualism: Language and Cognition, 14, 588-595.

Nicol, J., Teller, M., \& Greth, D. (2001). Production of verb agreement in monolingual, bilingual and secondlanguage speakers. In J. Nicol (Ed.), One mind, two languages: bilingual language processing (pp. 117-158). Oxford, UK: Blackwell.

Papp, K., Johnson, H. A., \& Sawi, O. (2015). Bilingual advantages in executive functioning either do not exist or are restricted to very specific and undetermined circumstances. Cortex, 69, 265-278.

Papp, K., Johnson, H. A., \& Sawi, O. (2016). Should the search for bilingual advantages in executive functioning continue? Cortex, 74, 305-214.

Pavlenko, A. (2014). The bilingual mind and what it tells us about language and thought. Cambridge, UK: Cambridge University Press.

Pountain, C. (2003). Exploring the Spanish language. London, UK: Hodder Arnold.

Schrauf, R. W., Pavlenko, A., \& Dewaele, J.-M. (2003). Bilingual episodic memory: An introduction. International Journal of Bilingualism, 7, 221-233.

Silva-Corvalán, C. (1994) Language contact and change: Spanish in Los Angeles. Oxford, UK: Clarendon Press.

Silva-Corvalán, C., \& Treffers-Daller, J. (Eds.) (2015). Language dominance in bilinguals: Issues of measurement and operationalization. Cambridge, UK: Cambridge University Press.

Slobin, D. I. (1996). Two ways to travel: Verbs of motion in English and Spanish. In M. Shibatani \& S. A. Thompson (Eds.), Grammatical constructions - Their form and meaning (pp. 195-219). Oxford, UK: Clarendon Press.

Slobin, D. I. (1997). Mind, code, and text. In J. Bybee, J. Haiman, \& S. Thompson (Eds.), Essays on language function and language type (pp. 437-467). Amsterdam, the Netherlands: John Benjamins.

Slobin, D. I. (2000). Verbalised events: A dynamic approach to linguistic relativity and determinism. In S. Niemeier \& R. Dirven (Eds.), Evidence for linguistic relativity (pp. 107-138). Amsterdam, the Netherlands: John Benjamins.

Slobin, D. I. (2003). Language and thought online: Cognitive consequences of linguistic relativity. In D. Gentner \& S. Goldin-Meadow (Eds.), Language in mind: Advances in the study of language and thought (pp. 157-191). Cambridge, MA: MIT Press.

Slobin, D. I. (2006). What makes manner of motion salient? Explorations in linguistic typology, discourse, and cognition. In M. Hickmann \& S. Robert (Eds.), Space in languages: Linguistic systems and cognitive categories (pp. 59-81). Amsterdam, the Netherlands: John Benjamins. 
Slobin, D. I. (2016). Thinking for speaking and the construction of evidentiality in language contact. In M. Güven, D. Akar, B. Öztürk, \& M. Kelepir (Eds.) Exploring the Turkish linguistic landscape: Essays in honor of Eser Erguvanli-Taylan [Studies in Language Companion Series 175] (pp. 105-120). Amsterdam, the Netherlands: John Benjamins.

Treffers-Daller, J. (2015). The construct of language dominance, its operationalization and measurement. In: C. Silva-Corvalan \& J. Treffers-Daller (Eds.) Language dominance in bilinguals: Issues of measurement and operationalization (pp. 235-265). Cambridge, UK: Cambridge University Press.

Trudgill, P. (2011). Sociolinguistic typology: Social determinants of linguistic complexity. Oxford, UK: Oxford University Press.

\section{Author biography}

[AQ: 11]

Appendix. participant response types (raw numbers in brackets).

Non-intentional events.

\begin{tabular}{|c|c|c|c|c|c|}
\hline $\begin{array}{l}\text { Item } \rightarrow \\
\text { Group }\end{array}$ & Balloon pop & Cup pushed & Tower crushed & Pen dropped & Bottle knocked \\
\hline M English & $\begin{array}{l}\text { The girl popped the } \\
\text { balloon. ( } 8 \text { ) } \\
\text { The balloon } \\
\text { popped. (9) } \\
\text { Other (3) }\end{array}$ & $\begin{array}{l}\text { She pushed the } \\
\text { cup off the sink. } \\
\text { (I2) } \\
\text { The cup fell into } \\
\text { the sink. (8) }\end{array}$ & $\begin{array}{l}\text { The woman } \\
\text { crushed the } \\
\text { tower. (I5) } \\
\text { The tower } \\
\text { crumbled } \\
\text { down. (4) } \\
\text { Other (I) }\end{array}$ & $\begin{array}{l}\text { The woman } \\
\text { dropped the } \\
\text { pen. (I7) } \\
\text { The pen } \\
\text { dropped out of } \\
\text { her hand. (2) } \\
\text { The pen fell. (I) }\end{array}$ & $\begin{array}{l}\text { She knocked the } \\
\text { bottle off the } \\
\text { table. }(16) \\
\text { The bottle fell } \\
\text { down/off the } \\
\text { table. (4) }\end{array}$ \\
\hline M Spanish & $\begin{array}{l}\text { Se le rompió } \\
\text { el globo (a la } \\
\text { muchacha) (20) }\end{array}$ & $\begin{array}{l}\text { Se le cayó el } \\
\text { vaso. (18) } \\
\text { Se cayó el } \\
\text { vaso (2) }\end{array}$ & $\begin{array}{l}\text { Se le rompió la } \\
\text { torre. (I7) } \\
\text { La torre se } \\
\text { rompió. }\end{array}$ & $\begin{array}{l}\text { Se le cayó el } \\
\text { bolido. (20) }\end{array}$ & $\begin{array}{l}\text { Se le cayó la } \\
\text { botella. (I5) } \\
\text { La botella se } \\
\text { cayó. (5) }\end{array}$ \\
\hline B English & $\begin{array}{l}\text { The (girl's) balloon } \\
\text { popped (by } \\
\text { accident) (I6). } \\
\text { The girl popped } \\
\text { the balloon } \\
\text { (accidentally).(3) } \\
\text { Other (I) }\end{array}$ & $\begin{array}{l}\text { The girl } \\
\text { knocked the } \\
\text { cup off the sink } \\
\text { (accidentally). } \\
\text { (10) } \\
\text { The cup fell into } \\
\text { the sink. }(10)\end{array}$ & $\begin{array}{l}\text { The tower fell } \\
\text { apart. (9) } \\
\text { The woman } \\
\text { accidentally } \\
\text { destroyed the } \\
\text { tower. (8) } \\
\text { Other (3) }\end{array}$ & $\begin{array}{l}\text { The pen fell out } \\
\text { of her hand. (5) } \\
\text { She (suddenly) } \\
\text { dropped the } \\
\text { pen. (15) }\end{array}$ & $\begin{array}{l}\text { The woman } \\
\text { pushed the bottle } \\
\text { (accidentally). } \\
\text { (13) } \\
\text { The bottle fell } \\
\text { down/ off the } \\
\text { table. (7) }\end{array}$ \\
\hline B Spanish & $\begin{array}{l}\text { Se rompió el globo } \\
\text { a la muchach a. (20) }\end{array}$ & $\begin{array}{l}\text { El vaso se cayó. } \\
(10) \\
\text { Se le cayó el } \\
\text { vaso. (10) }\end{array}$ & $\begin{array}{l}\text { Se rompió la } \\
\text { torre. }(12) \\
\text { La torre se le } \\
\text { rompió. (8) }\end{array}$ & $\begin{array}{l}\text { Se le cayó el } \\
\text { bolido. (20) }\end{array}$ & $\begin{array}{l}\text { Se cayó la botella. } \\
\text { (13) } \\
\text { Se le cayó la } \\
\text { botella. (7) }\end{array}$ \\
\hline
\end{tabular}


Appendix. (Continued)

Intentional events.

\begin{tabular}{|c|c|c|c|c|c|}
\hline $\begin{array}{l}\text { Item } \rightarrow \\
\text { Group }\end{array}$ & Balllon pop & $\begin{array}{l}\text { Doll } \\
\text { Pushed }\end{array}$ & Cup crushed & Magazine dropped & $\begin{array}{l}\text { Box } \\
\text { Knocked }\end{array}$ \\
\hline M English & $\begin{array}{l}\text { The girl popped } \\
\text { the balloon. (I0) } \\
\text { The balloon } \\
\text { popped/burst. } \\
\text { (9) } \\
\text { Other (I) }\end{array}$ & $\begin{array}{l}\text { She pushed the } \\
\text { doll off the bed. } \\
\text { (I3) } \\
\text { She pushed the } \\
\text { doll and it fell } \\
\text { down. (7) }\end{array}$ & $\begin{array}{l}\text { The woman } \\
\text { crushed the } \\
\text { cup. (12) } \\
\text { The woman } \\
\text { squeezed the } \\
\text { cup and it } \\
\text { cracked. (8) }\end{array}$ & $\begin{array}{l}\text { The woman } \\
\text { dropped the } \\
\text { magazine on the } \\
\text { floor. } \\
\text { (I5) } \\
\text { The woman threw } \\
\text { the magazine on } \\
\text { the floor. (5) }\end{array}$ & $\begin{array}{l}\text { She knocked the } \\
\text { box off (II) } \\
\text { The woman } \\
\text { pushed the box } \\
\text { and it fell down. } \\
\text { (9) }\end{array}$ \\
\hline M Spanish & $\begin{array}{l}\text { Rompió el globo. } \\
(20)\end{array}$ & $\begin{array}{l}\text { La niña empujó } \\
\text { la muñeca (20) }\end{array}$ & $\begin{array}{l}\text { La mujer } \\
\text { rompió el } \\
\text { vaso. }(20)\end{array}$ & $\begin{array}{l}\text { La mujer tiró la } \\
\text { revista al suelo. } \\
(20)\end{array}$ & $\begin{array}{l}\text { Empujó la caja. } \\
\text { (20) }\end{array}$ \\
\hline B English & $\begin{array}{l}\text { The girl made the } \\
\text { balloon pop (with a } \\
\text { needle). (I0) } \\
\text { The girl popped the } \\
\text { balloon on } \\
\text { purpose. ( } 8 \text { ) } \\
\text { The girl pierced the } \\
\text { balloon. (2) }\end{array}$ & $\begin{array}{l}\text { She pushed the } \\
\text { Barbie off the } \\
\text { bed. (20) }\end{array}$ & $\begin{array}{l}\text { The woman } \\
\text { crushed/ } \\
\text { destroyed } \\
\text { the cup. (20) }\end{array}$ & $\begin{array}{l}\text { She threw the } \\
\text { magazine on the } \\
\text { floor. (17) } \\
\text { She dropped the } \\
\text { magazine down on } \\
\text { purpose). (3) }\end{array}$ & $\begin{array}{l}\text { She pushed } \\
\text { the box off the } \\
\text { table (forcefullyl } \\
\text { angrily) (20) }\end{array}$ \\
\hline B Spanish & $\begin{array}{l}\text { La niña rompió el } \\
\text { globo. }(20)\end{array}$ & $\begin{array}{l}\text { La niña empujó } \\
\text { la muñeca de la } \\
\text { cama. (20) }\end{array}$ & $\begin{array}{l}\text { La mujer } \\
\text { rompió el } \\
\text { vaso. (20) }\end{array}$ & $\begin{array}{l}\text { La mujer tiró/botó } \\
\text { la revista al suelo. } \\
\text { (20) }\end{array}$ & $\begin{array}{l}\text { La mujer empujó } \\
\text { la caja.(20) }\end{array}$ \\
\hline
\end{tabular}

